CZASOPISMO INŻYNIERII LĄDOWEJ, ŚRODOWISKA I ARCHITEKTURY JOURNAL OF CIVIL ENGINEERING, ENVIRONMENT AND ARCHITECTURE

JCEEA, t. XXXIII, z. 63 (3/16), lipiec-wrzesień 2016, s. 413-420

\author{
Karolina SIEDLISKA ${ }^{1}$ \\ Agata ZDYB ${ }^{2}$
}

\title{
ZASTOSOWANIE WYBRANYCH BARWNIKÓW ORGANICZNYCH W BARWNIKOWYCH OGNIWACH SŁONECZNYCH
}

\begin{abstract}
Coraz większe potrzeby energetyczne świata oraz nacisk na aspekty ekologiczne wymuszają poszukiwanie nowych, bardziej efektywnych i tanich sposobów wytwarzania energii elektrycznej, stąd wynika wzrost zainteresowania w ostatnich latach barwnikowymi ogniwami słonecznymi (DSSC - Dye Sensitized Solar Cells). Głównym komponentem takiego ogniwa, który odpowiada za absorbcję promieniowania słonecznego padającego na jego powierzchnię, jest półprzewodząca warstwa nanocząstek $\mathrm{TiO}_{2}$ z zaadsorbowanym na niej barwnikiem. Barwnik działający jako sensybilizator jest adsorbowany na powierzchni ditlenku tytanu, ponieważ powoduje zwiększenie zakresu absorpcji promieniowania słonecznego przez oświetlaną elektrodę. W niniejszej pracy przedstawiono zastosowanie wybranych barwników organicznych (alizaryny, chinizaryny, ktecholu, parabutylokatechiny) oraz dwóch technik wytwarzania warstwy półprzewodzącej nanocząstek $\mathrm{TiO}_{2}$ (nanoszenie z roztworu koloidalnego lub pasty) do budowy ogniw DSSC. Wyznaczono widma absorpcji światła dla poszczególnych barwników i zmierzono sprawności ogniw w zależności od rodzaju zastosowanego barwnika oraz metody wytworzenia warstwy $\mathrm{TiO}_{2}$. Każdy z badanych sensybilizatorów trwale adsorbuje się na nanocząstkach $\mathrm{TiO}_{2}$ w czasie jednej doby. Wykorzystanie danych komponentów do budowy ogniwa pozwoliło na uzyskanie najwyższej sprawności rzędu 0,272\% w przypadku elektrody wykonanej z pasty oraz zaadsorbowanego na niej barwnika chinizaryny. Przedstawione w artykule wyniki badań pozwalają stwierdzić zasadność zastosowania wybranych barwników oraz konieczność dalszych badań nad zwiększeniem wydajności ogniw typu DSSC.
\end{abstract}

Słowa kluczowe: ogniwo barwnikowe (DSSC), fotowoltaika, substancje sensybilizujące, alizaryna, katechol, chinizaryna, parabutylokatechina

\footnotetext{
1 Autor do korespondencji / corresponding author: Karolina Siedliska, Uniwersytet Przyrodniczy w Lublinie, Katedra Fizyki, ul. Akademicka 13, 20-950 Lublin; tel. 81-445-69-05; karolina.siedliska@up.lublin.pl

2 Agata Zdyb, Politechnika Lubelska, Instytut Inżynierii Odnawialnych Źródeł Energii, ul. Nadbystrzycka 40B, 20-618 Lublin; tel. 81-538-47-47; a.zdyb@pollub.pl
} 


\section{Wprowadzenie}

Ograniczenie kosztów produkcji ogniw słonecznych jest obecnie podstawowym celem badań realizowanych w dziedzinie fotwoltaiki. Tym samym dużą szansę na rozwój upatruje się w barwnikowych ogniwach słonecznych, które są stosunkowo proste w konstrukcji i nie wymagają do konstrukcji budowy drogich i nieprzyjaznych środowisku materiałów. Mimo tego, że prace nad ogniwami elektrochemicznymi trwają już od wielu lat, to przełom w badaniach nastąpił dopiero po opracowaniu modelu ogniwa barwnikowego przez Michaela Graetzela i Briana O'Regana w 1991 roku [1]. Sprawność pierwszych ogniw barwnikowych wynosiła poniżej 7\% [2], dziś przy zastosowaniu nowoczesnych technik wytwarzania mezoporowatych półprzewodnikowych elektrod i nowych barwników sprawność przekracza nawet 13,8\% [3].

Absorpcja światła w ogniwach DSSC następuje w warstwie półprzewodnika (najczęściej $\mathrm{TiO}_{2}$ ), na którego powierzchni jest zaadsorbowany barwnik. Dobór odpowiedniego barwnika determinuje w dużym stopniu wydajność ogniwa. Jako substancje sensybilizujące wykorzystuje się zarówno barwniki organiczne, metaloorganiczne, jak i nieorganiczne. Do tej pory najwyższe wydajności ogniw uzyskiwano dla kompleksów rutenu oraz barwników porfirynowych (13\%) [4], ale ze względu na ich dużą toksyczność i relatywnie wysoki koszt produkcji próbuje się je zastąpić innymi substancjami. Uwaga wielu naukowców skupia się głównie na barwnikach występujących w przyrodzie, które charakteryzują się dużą dostępnością i różnorodnością. Pomimo uzyskiwania sprawności maksymalnie rzędu 2,9\% (dla ekstraktu z Brassica olercea) [5] to właśnie barwniki pochodzenia naturalnego np. flawonoidy [6,7], wydają się być obecnie dobrym materiałem na substancje sensybilizujące.

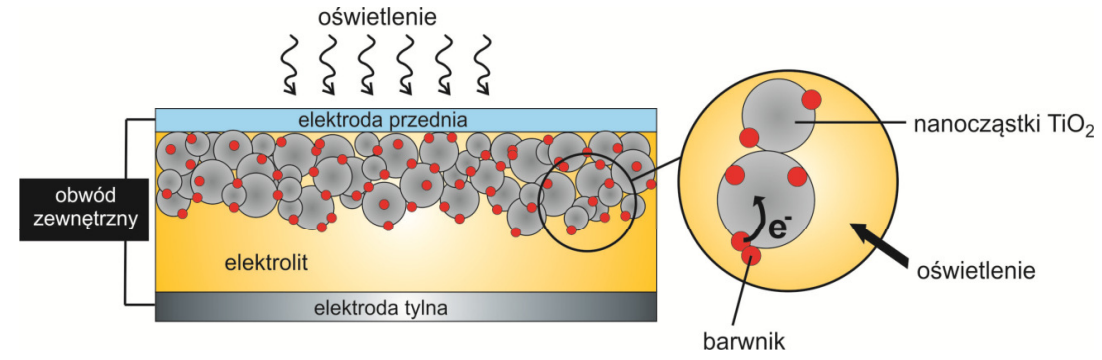

Rys. 1. Budowa barwnikowego ogniwa słonecznego

Fig. 1. Schematic of dye sensitized solar cell

Na Rys. 1 przedstawiono schemat budowy barwnikowego ogniwa słonecznego. Kiedy powierzchnia ogniwa jest oświetlana, zachodzi absorpcja fotonu przez barwnik, co prowadzi do wzbudzenia jego cząsteczki. Następuje wówczas iniekcja elektronu do pasma przewodnictwa półprzewodnika i pozostała cząsteczka barwnika ma postać jonu dodatniego $\mathrm{S}^{+}$. Wprowadzony do pasma prze- 
wodnictwa elektron przechodzi przez mezoporowatą warstwę półprzewodnika i dociera do przedniej elektrody, a stamtąd przechodzi do zewnętrznej części obwodu elektrycznego. Po przejściu przez przeciwelektrodę platynową (elektrodę tylną) elektron redukuje cząstkę elektrolitu $\mathrm{I}^{-} \mathrm{I}^{3-}$, co powoduje reakcję regeneracji cząsteczki barwnika i obwód się zamyka [1].

W niniejszej pracy przedstawiono wykorzystanie czterech barwników organicznych w roli sensybilizatorów w ogniwach typu DSSC: alizaryny, chinizaryny, katecholu i parabutylokatechiny, które wybrano ze względu na brak dotychczasowych doniesień literaturowych dotyczących ich zastosowań do budowy ogniw typu DSSC. Przeprowadzono badania wydajności ogniw w zależności od rodzaju zastosowanej substancji sensybilizującej, a także od sposobu wytworzenia warstwy tytanowej. Dla wszystkich barwników określono także widma absorpcji promieniowania w zakresie światła widzialnego.

\section{Opis procedury badawczej}

\subsection{Preparatyka substancji wykorzystanych do badań}

Koloidalną zawiesinę nanocząstek ditlenku tytanu o stężeniu $100 \mathrm{mM} \cdot \mathrm{dm}^{-3}$ w bezwodnym etanolu $(99,8 \%)$ otrzymano metodą hydrolizy izopropanolanu tytanu [8]. Pastę sporządzano zaś przy użyciu gotowych nanocząstek ditlenku tytanu zakupionych w postaci proszku o nazwie handlowej DEGUSSA P-25. Elektrody nanoszono na szkło, pokryte warstwą przewodzącego tlenku ITO (indium thin oxide), odpowiednio poprzez nakrapianie roztworu koloidalnego lub nanoszenie pasty.

Roztwory substancji sensybilizujących wykonano poprzez rozpuszczenie barwników w bezwodnym etanolu. W ten sposób otrzymano roztwory nasycone, w których zanurzano na 24 godziny szkła przewodzące z naniesionymi warstwami $\mathrm{TiO}_{2}$ w celu uzyskania kompleksów sensybilizator- $\mathrm{TiO}_{2}$.

\subsection{Konstrukcja barwnikowego ogniwa słonecznego i układ pomiarowy}

Badane ogniwa barwnikowe budowano w taki sposób, aby uzyskać następującą kolejność elementów: ITO/TiO $/$ /barwnik/elektrolit/Pt/ITO.

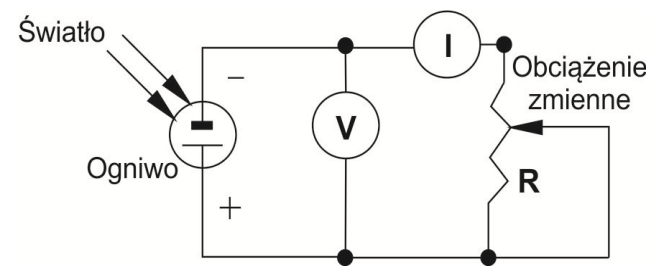

Rys. 2. Układ doświadczalny do pomiaru charakterystyk prądowo-napięciowych ogniw DSSC

Fig. 2. Experimental setup for measuring the current-voltage characteristics of DSSC 
Do wyznaczania parametrów pracy badanych ogniw barwnikowych wykorzystano układ pomiarowy, który składał się z lampy halogenowej, amperomierza i woltomierza oraz rezystora o regulowanym obciążeniu (Rys. 2). Do pomiarów wykorzystano mierniki firmy PHYWE oraz lampę halogenową KFB videolight 6 firmy KAISER, typ 93304, o mocy $1000 \mathrm{~W}$ i barwie światła $3400 \mathrm{~K}$ używaną w przypadku pomiarów ogniw z koloidalną warstwą $\mathrm{TiO}_{2}$. W przypadku stosowania lampy halogenowej ogniwo przesłaniano filtrem podczerwieni w celu eliminacji efektów temperaturowych, powodująceych ewaporację elektrolitu. Ogniwa z warstwą $\mathrm{TiO}_{2}$ wytworzoną z preparatu DEGUSSA P-25 badano w warunkach oświetlenia biurowego. Natężenie światła oświetlającego ogniwo wynosiło odpowiednio: w przypadku stosowania lampy halogenowej $36,6 \mathrm{~mW} \cdot \mathrm{m}^{-2}$, zaś dla warunków oświetlenia biurowego $-0,35 \mathrm{~mW} \cdot \mathrm{m}^{-2}$. Wyznaczenie widm adsorpcji barwników przeprowadzono przy użyciu spektrofotometru UV/VIS, Model U-1500, firmy HITACHI.

\section{Wyniki badań}

Badanie własności barwników poprzedzono wyznaczeniem widma absorpcji czystego ditlenku tytanu. Z przeprowadzonej analizy wynika, że zakres absorpcji promieniowania dla czystego ditlenku jest bardzo wąski i zawiera się w zakresie długości fal poniżej $350 \mathrm{~nm}$ (Rys. 3b). Widoczne jest wyraźnie, że bez zastosowania sensybilizatorów w ogniwach barwnikowych ich sprawność byłaby bardzo niska. Uzyskane widma absorbcji dla roztworów poszczególnych barwników oraz ich kompleksów z ditlenkiem tytanu przedstawiono na Rys. 3.

$\mathrm{W}$ przypadku alizaryny, która jest czerwonym barwnikiem pochodzenia naturalnego pozyskiwanego z korzenia marzanny barwierskiej (Rubia tinctorum), w widmie absorpcji widoczne są dwa wyraźne maksima przy długości fali około $440 \mathrm{~nm}$ oraz poniżej $300 \mathrm{~nm}$. Jednak po utworzeniu kompleksu z ditlenkiem tytanu następuje ich przesunięcie w stronę długofalową. Pojawia się wyraźne maksimum absorpcji przy długości fali $500 \mathrm{~nm}$.

Dla chinizaryny, barwnika o barwie czerwono-brązowej będącego pochodną alizaryny, w widmie absorpcji jest widoczne maksimum absorpcji przy długości fali około $475 \mathrm{~nm}$ oraz w zakresie ultrafioletu. Utworzenie kompleksu barwnika $\mathrm{z}$ ditlenkiem tytanu nie powoduje istotnych zmian $\mathrm{w}$ widmie absorbcji, a jest jedynie złożeniem spektrum pochłaniania promieniowania dla obu związków.

Wolny katechol, barwnik dostępny w sprzedaży jako proszek o barwie beżowej, posiada widoczne pasmo absorpcji w zakresie długości fal poniżej $300 \mathrm{~nm}$. Po utworzeniu kompleksu z ditlenkiem tytanu następuje przesunięcie maksima absorpcji w stronę długofalową. Wyraźne piki są widoczne przy długościach fal $400 \mathrm{~nm}$ i poniżej $350 \mathrm{~nm}$.

Parabutylokatechina, barwnik o barwie kremowej, będąca pochodną katecholu wykazuje podobnie jak on maksimum absorpcji w zakresie ultrafioletu, a także przy długości fali $410 \mathrm{~nm}$. Pojawienie się drugiego piku w tym przypad- 
ku związane jest prawdopodobnie $\mathrm{z}$ występowaniem butylowej grupy funkcyjnej. Po utworzeniu kompleksów barwnika $\mathrm{z}$ ditlenkiem tytanu, nie zauważa się istotnej zmiany. Maksima absorpcji znajdują się w tych samych zakresach długości fal, jakie są charakterystyczne dla obu tych substancji.

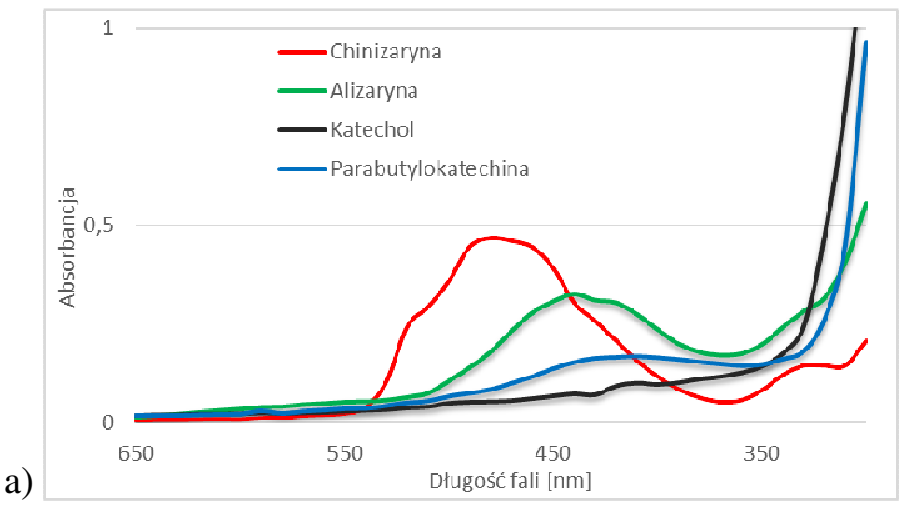

a)

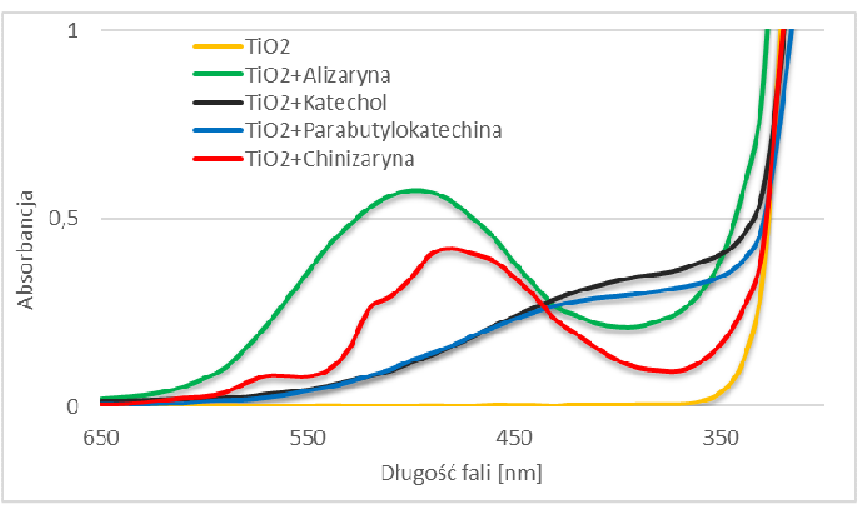

Rys. 3. a) Widmo absorpcji roztworów poszczególnych barwników, b) mieszaniny $\mathrm{TiO}_{2}+$ barwnik oraz nanocząstek $\mathrm{TiO}_{2}$ w temperaturze pokojowej

Fig. 3. a) Absorption spectrum of dyes solution, b) mixture of dye $+\mathrm{TiO}_{2}$ solution and $\mathrm{TiO}_{2}$ nanoparticles solution at room temperature

\section{Analiza wyników}

Sprawność $(\eta)$ barwnikowych ogniw słonecznych wyznaczono ze wzoru:

$$
\eta=\frac{U_{O C} \cdot I_{S C} \cdot F F}{S \cdot A} \cdot 100 \%
$$

gdzie: $U_{O C}$ - napięcie obwodu otwartego,

$I_{S C}-$ prąd zwarcia, 
$S$ - powierzchnia czynna ogniwa,

$A$ - moc promieniowania padającego na powierzchnię ogniwa,

$F F$ - współczynnik wypełnienia charakterystyki - parametr określający jakość ogniwa słonecznego wyrażany wzorem:

$$
F F=\frac{U_{M P P} \cdot I_{M P P}}{U_{O C} \cdot I_{S C}}
$$

gdzie: $U_{M P P}-$ napięcie w punkcie mocy maksymalnej,

$I_{M P P}$ - wartość natężenia prądu w punkcie mocy maksymalnej.

Wyniki przeprowadzonych obliczeń wykazują, iż sprawności ogniw z elektrodą półprzewodnikową utworzoną z pasty z preparatu P-25 DEGUSSA są wyższe niż w przypadku wykorzystania ditlenku tytanu w postaci nanocząstek koloidalnych. Wpływ na otrzymane wartości miał także rodzaj zastosowanego barwnika. W przypadku pasty najlepsze wyniki otrzymano dla chinizaryny i parabutylokatechiny, a dla koloidu - alizaryny i chinizaryny.

Na podstawie otrzymanych wyników przypuszcza się, że otrzymanie niższych sprawności w przypadku koloidu może być spowodowane zbyt małą ilością nanocząstek ditlenku tytanu tworzących elektrodę, a co za tym idzie niskim współczynnikiem porowatości powierzchni. Mogło to mieć wpływ na niski współczynnik adsorpcji barwników i zmniejszać efektywność zachodzących reakcji oraz utrudniać swobodny przepływ ładunku w złączu.

Sprawność ogniw obniżyły także problemy z zastosowaniem ciekłego elektrolitu. W związku z tym, iż nie znaleziono efektywnego sposobu uszczelnienia ogniw, mógł on swobodnie wyciekać i odparowywać. Zastosowanie lampy halogenowej spowodowało podwyższenie temperatury układu i zwiększenie ewaporacji elektrolitu. Z drugiej strony wzrost temperatury spowodował obniżenie przewodności poszczególnych elementów ogniwa.

Wyższa efektywność $\mathrm{w}$ przypadku pasty zawiązana jest prawdopodobnie z uzyskaniem warstwy $\mathrm{TiO}_{2}$ o większej grubości, wyższego współczynnika porowatości powierzchni, większej ilości zaadsorbowanego barwnika, oraz mniejszego prawdopodobieństwa wyciekania elektrolitu ze względu na wypełnienie porów. Mogło to wpłynąć na poprawę kinetyki reakcji zachodzących w ogniwie, poprzez wzajemne przenikanie się poszczególnych warstw i swobodniejszy transport ładunków elektrycznych.

Różnice w sprawnościach dla różnych substancji sensybilizujących wynikają z różnic $\mathrm{w}$ widmach absorpcji, a także $\mathrm{z}$ ich struktury chemicznej, która ma wpływ na rodzaj wiązań tworzonych z ditlenkiem tytanu i stopień adsorpcji na jego powierzchni. Najlepsze wyniki osiągnięto dla chinizaryny zaadsorbowanej na paście $\mathrm{z}$ ditlenku tytanu, czyli $\mathrm{FF}=0,37$ i sprawność $\eta=0,272 \%$, pozostałe wyniki przedstawiono w tabeli 1 . 
Tabela 1. Parametry pracy badanych ogniw barwnikowych

Table 1. Operating parameters of conducted solar cells

\begin{tabular}{|c|c|c|c|}
\hline Badany barwnik & Rodzaj elektrody & FF & $\boldsymbol{\eta}[\mathbf{\%}]$ \\
\hline \multirow{2}{*}{ parabutylokatechina } & pasta & 0,34 & 0,14 \\
\cline { 2 - 4 } & koloid & 0,41 & 0,004 \\
\hline \multirow{2}{*}{ katechol } & pasta & 0,36 & 0,079 \\
\cline { 2 - 4 } & koloid & 0,4 & 0,002 \\
\hline \multirow{2}{*}{ alizaryna } & pasta & 0,37 & 0,017 \\
\cline { 2 - 4 } & koloid & 0,52 & 0,009 \\
\hline \multirow{2}{*}{ chinizaryna } & pasta & 0,39 & 0,272 \\
\cline { 2 - 4 } & koloid & 0,7 & 0,008 \\
\hline
\end{tabular}

\section{Wnioski}

Z przeprowadzonych badań i analizy otrzymanych wyników wynika, że:

- sprawność barwnikowych ogniw słonecznych przede wszystkim zależy od zastosowanej elektrody półprzewodnikowej i rodzaju zaadsorbowanego barwnika;

- zastosowanie gotowego preparatu nanocząstek DEGUSSA P-25 pozwala osiągać wyższą efektywność niż użycie roztworu koloidalnego, a poza tym wytworzenie elektrody w tym przypadku jest szybsze i łatwiejsze;

- otrzymane niewielkie sprawności w przypadku roztworu koloidalnego prawdopodobnie związane są z jego zbyt niskim stężeniem molowym;

- struktura chemiczna barwnika ma wpływ na jego właściwości absorpcyjne. Zaobserwowano, iż niewielka zmiana strukturze sensybilizatora np. poprzez zmianę konfiguracji lub dodanie grupy funkcyjnej może mieć znaczący wpływ na widmo absorpcji, tak jak w przypadku chinizaryny, przy zastosowaniu której osiągnięto najlepsze sprawności zarówno dla pasty, jak i koloidu;

- rodzaj zaadsorbowanego barwnika ma znaczący wpływ na zakres absorbowanego promieniowania przez ogniwo;

- zastosowanie pasty z nanocząstek ditlenku tytanu pozwala na zmniejszenie efektów związanych z wyciekaniem i parowaniem elektrolitu;

- na sprawność ogniwa wpływ mają warunki pracy. Wzrost temperatury urządzenia znacząco pogarsza uzyskiwane parametry i konieczne jest zastosowanie rozwiązań przeciwdziałających tym efektom, takich jak np. filtr podczerwieni;

- badania wyokazały, że przy zastosowaniu danego układu pomiarowego i najbardziej optymalnej kombinacji wykorzystanych komponentów ogniwa można osiągnąc sprawność wynoszącą w przybliżeniu $0,3 \%$.

\section{Literatura}

[1] Grätzel M., Dye-sensitized solar cells, Journal of Photochemistry and Photobiology C: Photochemistry Reviews 4, 2003, pp. 145-153.

[2] Grätzel M., Solar Energy Conversion by Dye-Sensitized Photovoltaic Cells, Inorganic Chemistry 44, 2005, pp. 6841-6851. 
[3] Sharma G. D., Daphnomili D., Gupta K.S.V., Gayathri T., Singh S.P., Angaridis P.A., Kitsopoulos T.N., Tasise D., Coutsolelos A.G., Enhancement of power conversion efficiency of dye-sensitized solar cells by co-sensitization of zinc-porphyrin and thiocyanate-free ruthenium(II)- terpyridine dyes and graphene modified $\mathrm{TiO}_{2}$ photoanode, RSC Advances 3, 2013, pp. 22412-22420.

[4] Mathew S., Yella A., Gao P., Humphry-Baker R., Curchod B.F.E., Ashari-Astani N., Tavernelli I., Rothlisberger U., Nazeeruddin M.K., Grätzel M., Dye-sensitized solar cells with $13 \%$ efficiency achieved through the molecular engineering of porphyrin sensitizers, Nature Chemistry 6, 2014, pp. 1-6.

[5] Li Y., Ku S.-H., Chen S.-M., Ali A., AlHemaid F.M.A, Photoelectrochemistry for Red Cabbage Extract as Natural Dye to Develop a Dye-Sensitized Solar Cells, Interational Journal of Electrochemical Science 8, 2013, pp. 1237-1245.

[6] Zdyb A., Krawczyk S., Characterization of adsorption and electronic excited states of quercetin on titanium dioxide nanoparticles, Spectrochimica Acta Part A: Molecular and Biomolecular Spectroscopy, vol. 157, 2016, pp. 197-203.

[7] Zdyb A., Krawczyk S., Adsorption and electronic states of morin on $\mathrm{TiO}_{2}$ nanoparticles, Chemical Physics, vol. 443, 2014, pp. 61-66.

[8] Kamat P.V., Bedja I., Hotchandani S., Photoinduced charge transfer between carbon and semiconductor clusters. One-electron reduction of $\mathrm{C}_{60}$ in colloidal $\mathrm{TiO}_{2}$ semiconductor suspensions, Journal of Physical Chemistry 98, 1994, pp. 9137-9142.

\section{USING OF SELECTED ORGANIC DYES IN DYE SENSITIZED SOLAR CELLS}

\section{S u m m a r y}

Considering the increasing global demand for energy and the harmful ecological impact of the conventional energy sources, it is obvious that development of clean and renewable energy sources is a necessity. Nowadays, dye sensitized solar cells (DSSC) represent one of the most promising methods for future large-scale conversion sunlight into electricity. The main component of DSSC is the semiconducting layer of $\mathrm{TiO}_{2}$ nanoparticles with adsorbed dye, which is responsible for absorption of the solar radiation incidenting on the surface. Sensitizing dye is adsorbed onto the surface of titanium dioxide layer so as to increase the extent of absorption of solar radiation by irradiated electrode. In the following paper, application of four selected organic dyes (alizarin, catechol, quinizarin and 4-tertbutylocatechol) and two techniques of deposition the $\mathrm{TiO}_{2}$ nanoparticles mesoporous layers on conducting glass as electrodes (application from colloidal solution or paste) were studied. The light absorption spectrum was determined for each dye and the efficiency of the cells was measured depending on the type of dye and the deposition method of titanium dioxide conducting layer. Each sensitizer dye was adsorbed on $\mathrm{TiO}_{2}$ surface by dipping in a dye solution for one day. The use of selected components for the cell construction made it possible to achieve the highest efficiencies of $0.272 \%$, which were obtained with electrodes covered by titanium paste and the quinizarin dye. The results of the research presented in the following paper allow to determine the validity of selected dyes and the necessity for further research on the issue of increasing the efficiency of DSSC type cells.

Keywords: dye sensitized solar cell, photovoltaic, sensitizer compounds, alizarin, catechol, quinizarin, 4-tert-butylocatechol

DOI:10.7862/rb.2016.224

Przestano do redakcji: 23.05.2016 $r$.

Przyjęto do druku: 30.11 .2016 r. 